\section{CULTURA ESCOLAR E EXPERIÊNCIA EDUCACIONAL NO MEIO RURAL: ESTUDO HISTÓRICO DO GRUPO ESCOLAR COMENDADOR PEDRO MORGANTI (ARARAQUARA-SP, 1942/1988)}

Reginaldo Anselmo Teixeira ${ }^{1}$ Rosa Fátima de Souza ${ }^{2}$

Resumo: O presente estudo teve como objetivo investigar a história de uma escola primária rural criada nas terras pertencentes à Usina Tamoio, município de Araraquara, no período de 1942 a 1988. A decisão pelo corte cronológico se justifica pela data de sua criação como Grupo Escolar Rural, sugerida pelos documentos encontrados, até a data em que foi temporariamente desativada. Este estudo pretendeu dialogar com as fontes documentais encontradas no interior da escola, assim como com a legislação que a ordenava juridicamente, na tentativa de sistematizar a relação existente entre os diversos atores que a compunham, e a relação com a comunidade em que estava inserida. A partir do diálogo com as fontes documentais, buscamos apresentar vestígios desta micro-história que possam nos levar à uma melhor visualização da cultura escolar da referida instituição no sentido de entender como esta escola desempenhou sua função política, social e cultural no decorrer do tempo.

Palavras-chave: Grupo Escolar Rural; Cultura Escolar; História da Escola Primária; Ensino Rural.

'Doutorando do Programa de Pós-Graduação em Educação da Faculdade de Filosofia e Ciências UNESP Marília-SP. Professor na Rede Municipal de Educação de Araraquara/SP. Email: selmoteixeira@hotmail.com

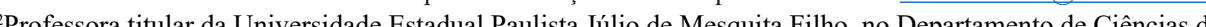
Educac̃o e Professor do Progra de Pós-Gadpacão en Ed Educação e Professora do Programa de Pós-Graduação em Educação da Faculdade de Filosofia e Ciências UNESP/Campus de Marília.
Abstract: The present study had as objective to investigate the history of a rural primary school created in the lands belonging to the Usina Tamoio, municipality of Araraquara in the São Paulo state, from 1942 to 1988. The decision by chronological cut is justified by the date of its creation as Rural School Group, suggested by the documents found, until the date when it was temporarily deactivated. This study aimed to dialogue with the documentary sources found inside the school, as well as with the legislation that legally ordered it, in an attempt to systematize the relationship between the various actors who composed it, and the relationship with the community in which it was inserted. From the dialogue with documentary sources, we seek to present traces of this micro-history that can lead us to a better view of school culture of the institution in order to understand how this school played its political role, social and cultural development over time.

Keywords: Rural School Group; School Culture; History of Elementary School; Rural Education.

\section{Introdução}

O Grupo Escolar Pedro Morganti foi criado em 1942. Este grupo escolar foi instalado na Fazenda Bela Vista, uma fazenda de café que foi incorporada na década de 1930 ao império Morganti. Esta fazenda foi integrada ao conglomerado de fazendas que compunham as terras da Usina Tamoio, passando a ser chamada de Secção Bela Vista da Usina Tamoio, ou ainda Secção Bela Vista do Chibarro em alusão ao rio que a delimita. Durante o período de apogeu do cultivo da cana de açúcar, esta escola atendia aos filhos dos empregados da parte industrial e agrícola da usina. Estas relações de trabalho, tanto industriais quanto agrícolas, faziam com que houvesse no interior desta instituição de ensino alunos de diferentes níveis sócio-econômicos, pois estudavam juntos os filhos dos diferentes tipos de trabalhadores da usina, colonos, motoristas, administradores, ferroviários, comerciantes, entre outros. No entanto, temos que entendê-la como uma escola voltada prioritariamente aos filhos dos trabalhadores ligados direta ou indiretamente ao trabalho na agricultura.

A delimitação temporal estabelecida para a realização desta pesquisa abrange o período de criação que se inicia com a criação do Grupo escolar Pedro Morganti e termina no momento em que as terras da Secção Bela 
Vista são desapropriadas para fins de Reforma Agrária e ocupadas pelas famílias que passaram a compor o Assentamento Bela Vista do Chibarro.

Este estudo está fundamentado teoricamente na história cultural inglesa, particularmente na obra de Edward Palmer Thompson (1987). Como assinala Faria Filho (2005), a relevância da utilização das obras desse historiador inglês no campo da educação justifica-s pela dimensão política que é fundamental na obra de Thompson e se desdobra numa exigência ética de comprometimento do historiador com o seu tempo, além de uma sensibilidade para com os problemas dos esquecidos pela história. No caso deste trabalho houve uma preocupação em entender o modo como a instituição escolar se apresentava aos filhos dos trabalhadores e tentar perceber, mesmo através dos silêncios, como estes se relacionavam com a educação escolarizada que lhes era oferecida. Vasculhamos a documentação no sentido de reconstruir como este processo de escolarização se processava.

Buscou-se nesta pesquisa articular experiência e cultura como conceitos de junção, que articulados, passam a constituir um ponto de intersecção entre estrutura e processo, entre as determinações objetivas do ser social e a possibilidade do agir e da intervenção humana. As experiências vividas dentro da instituição de ensino quando se tornam permanentes por um período de tempo, se transformam em práticas que passam a compor a cultura escolar.

A propósito dessa categoria pautamos a investigação na concepção de Viñao Frago (1995) que concebe cultura escolar como o conjunto de aspectos institucionalizados que caracterizam a escola como organização. Isso inclui práticas e condutas, modos de vida, hábitos e ritos, a história cotidiana do fazer escolar (objetos materiais), função, uso, distribuição no espaço, materialidade física, simbologia, introdução, transformação, desaparecimento e modos de pensar, bem como as idéias compartilhadas. Ou ainda de um modo mais geral, a cultura escolar é toda a vida escolar: fatos e idéias, mentes e corpos, objetos e condutas, modos de pensar, dizer e fazer.

Dessa maneira pudemos observar como a cultura escolar do Grupo Escolar Comendador Pedro Morganti se apresentou sob diferentes feições durante o passar dos tempos. Percebemos como sofreu interferências legais, e para isso se fez necessário o estabelecimento de um paralelo entre o desenvolvimento da instituição e o desenvolvimento de legislações, de Programas ou de Campanhas institucionais.

Com relação a uma interpretação de cultura escolar relacionada ao conceito de ordenamento jurídico, ou seja, relacionada com uma legislação que a prescreve, tivemos que buscar nas fontes, principalmente nas atas de reuniões pedagógicas, indícios de como as prescrições legais foram incorporadas e postas em prática. Partimos de um olhar que observava as atas de reuniões pedagógicas como um lócus de reinterpretação e reconfiguração das leis, pois em cada passo da hierarquia onde se encontravam os sujeitos escolares, havia uma intencionalidade. Nesse sentido, entender como o corpo docente se apropriava das prescrições legais e quais os mecanismos utilizados para colocá-las em prática em seu cotidiano, pareceu-nos um excelente caminho em direção à reconstrução de uma possível cultura escolar da instituição em questão. No entanto, ao não percebermos vozes que representavam o corpo docente, nos restou interpretar o silêncio, a ausência delas, como uma característica da cultura escolar do grupo escolar pesquisado. A falta de vozes, atrelada a uma realidade onde as reuniões pedagógicas serviam como reuniões de prescrições, do que se deveria e do que não se deveria, nos levou a intuir sobre um certo ranço de autoritarismo para com o corpo docente. Todavia, há nas atas disponíveis, por várias vezes, a orientação para que os professores não submetessem seus alunos a castigos físicos e nem a humilhações dentro da sala de aula. A recomendação era que os levassem até a diretoria para as devidas sanções. $\mathrm{O}$ fato de estas recomendações persistirem no tempo, nos levou a pensar também na relação dos professores com os alunos indisciplinados, como uma relação conflituosa, baseada muitas vezes, na força física. É certo que não podemos tentar generalizações. Não obstante, o que tentamos buscar foram justamente as relações que estão nas entrelinhas, os conflitos que não figuram objetivamente e deliberadamente nos registros documentais.

Para a realização deste estudo utilizamos fontes encontradas no arquivo da Escola Municipal de Ensino Fundamental do Campo "Prof. Hermínio Pagôtto", pertencentes ao Grupo Escolar Comendador Pedro Morganti. Foi necessário organizar os documentos que se encontravam guardados num dos armários da escola na sala da dispensa. Ao todo foram encontrados 217 documentos referentes ao período delimitado para o estudo: Livros de chamadas, Livros pontos, de Matrículas, de Pessoal, Inventário, Ata das Reuniões Pedagógicas, Livros de Recortes, Mapas de Movimento, Atestados, laudos e Guias, Caixa Escolar, Livro de Correspondências, Memorandos e Circulares, Merenda Escolar, entre outros, que nos serviram como fontes valiosas para o estudo histórico da instituição educativa e da cultura escolar, 
contribuindo para os estudos da história da educação brasileira.

Neste texto buscamos inicialmente caracterizar a referida escola primária rural, levantando informações oriundas dos Livros de Matrículas, sobre os alunos e sobre a comunidade onde estava inserida. Na seqüência, examinamos as Atas de Reuniões Pedagógicas buscando vestígios da cultura escolar do período estudado dando destaque para as práticas de educação rural.

Usina tamoio: A história de um Império nos campos de Araraquara

O Grupo Escolar Comendador Pedro Morganti estava situado nas terras da antiga Usina Tamoio, pertencentes à família Morganti. É impossível discorrer sobre a referida instituição de ensino sem apresentar o significado dessa usina e de seus proprietários para a cidade de Araraquara, para o Estado de São Paulo, para o Brasil e toda a América do Sul. Para tal empreitada, utilizamos principalmente os estudos realizados por Caires (1993).

A Usina Tamoio nasceu em 1917 com status de usina, embora tenha sido originalmente denominada de "Engenho Fortaleza". Organizada por Pedro Morganti ela surgiu num cenário de crise e decadência da produção cafeeira e início dos áureos tempos da cana de açúcar. Nela coexistem, até a segunda metade da década de 1920, essas duas culturas agrícolas, quando passou a se apresentar como a única usina açucareira de Araraquara, respondendo por $12 \%$ da produção total do Estado de São Paulo.

Segundo a interpretação de Pacheco (1988), outro historiador preocupado com a relação entre o cultivo do café e a urbanização de Araraquara e São Carlos no período de 1920 a 1940, a Usina Tamoio já se apresentava como um dos mais importantes estabelecimentos do setor em São Paulo. Sobre a expansão de suas terras pela região, podemos mencionar um grande salto, ao comprar as propriedades vizinhas, em geral antigas fazendas cafeeiras, afetadas na sua grande maioria pela crise mundial do final da década de 1920. Essa acumulação de terras e riquezas fez com que, em 1946, ao bater o recorde continental de produção de açúcar, esta usina fosse oficialmente considerada a maior indústria sucro-alcooleira do país e da América do Sul. ${ }^{3}$

É valido mencionar que o fundador Pedro Morganti faleceu no ano de 1941, deixando para a sua família o controle do império do açúcar, formado, naquela época, por 5.278 alqueires que abrigavam de 7.000 a ${ }^{3}$ Conforme Álbum de Araraquara de 1948. p.124
10.000 trabalhadores habitantes. A Usina Tamoio, que também controlava financeiramente a Refinaria Paulista S/A, tinha em sua população trabalhadora dividida entre agricultura e industrialização, além do regime de colonato que perdurou até o início da década de 1960, colonos de cana, assalariados agrícolas, camaradas, operários de fabricação, manutenção, empregados da administração, dos escritórios, dos transportes, inclusive do transporte ferroviário. Em toda sua extensão a usina era povoada por aproximadamente 1.500 casas. Possuía oficinas mecânicas, um ambulatório médico localizado na Seção Bela Vista, ambulância, prédio do Circulo Operário Católico, um campo de pouso para aviões de pequeno porte, pelo menos uma capela em cada seção, uma biblioteca, sala de projeção de filmes e peças teatrais, um grande estádio esportivo, armazém, açougue, farmácia, padaria, loja de ferragens, loja de tecidos e armarinhos, torrefação de café, fábrica de sabão, leiteria, sorveteria, instituto de beleza, gabinete dentário, agência postal, serviço telefônico, um serviço de ônibus que ligava a cidade de Araraquara à estação de trem Tamoio, uma Catedral religiosa, além de uma hospedaria similar a um hotel citadino (CAIRES, 1993. p.66). Ao que parece a usina assegurava que todas as condições e necessidades de seus trabalhadores fossem satisfeitas ali mesmo.

A partir dos estudos da pesquisadora, pudemos verificar que, desde a década de 1930, a Usina Tamoio já mantinha em seu território um Grupo Escolar de bom porte e seis escolas isoladas. Data de 1939, a primeira turma de formandos do Grupo Escolar D. Giannina Morganti, situado na sede da usina, lugar onde havia uma vila com casarões e as instalações industriais, ou seja, a moenda propriamente dita. É importante ressaltar que a referida usina era um grande latifúndio, com sua extensão de terras ligando as cidades de Araraquara aos limites da cidade de Ibaté, localizada a uma distância de 27 quilômetros, assim como aos limites da cidade de Guarapiranga, distante 26 quilômetros de Araraquara, por isso, era subdividida em seções, onde existiam colônias de casas. Neste sentido, a Seção Bela Vista, possuía uma colônia com aproximadamente 150 casas, um posto de saúde, uma escola, uma igreja católica e uma estação de trem. No entanto, foi sob o domínio da segunda geração da família, que Hélio Morganti elevou duas das seis escolas isoladas à condição de Grupo Escolar, sendo uma delas situada na Seção Bela Vista da usina, o objeto de estudo deste trabalho: o Grupo Escolar Comendador Pedro Morganti.

O fato de encontrarmos a partir da década de 1930 nas terras deste 
conglomerado agro-industrial seis escolas isoladas e um Grupo Escolar, demonstra quanto prestígio e força política exerciam os Morganti junto ao estado para garantir em suas terras estas instituições educacionais. Sobre a instalação do primeiro grupo escolar o trabalho de Flores (2015) aponta a data de 07 de junho de 1935 e indica que a instalação do Grupo Escolar da Usina Tamoio constituiu um agrupamento de várias escolas mistas (também conhecidas como escolas isoladas) que ficavam nas seções próximas da sede. Em 1942 foi construído o segundo grupo escolar dentro das terras da usina, o Grupo Escolar Pedro Morganti. Não podemos nos esquecer que os grupos escolares durante a primeira metade do século XX foram concebidos como indicadores da modernidade da educação paulista, tais instituições foram vistas como símbolo da escola republicana e se tornaram símbolos da escola pública paulista ${ }^{4}$.

Em meados dos anos de 1960, a usina completou seu sistema educacional, a partir da aprovação do projeto de lei $n^{\circ} 846 / 58$, de autoria do Deputado Estadual Scalamandré Sobrinho, instituindo o "Ginásio Estadual da Usina Tamoio" que funcionava no Grupo Escolar D. Giannina Morganti localizado nas instalações da sua sede.

Em 1953, ao liderar a produção sucro-alcooleira do Estado de São Paulo, a Usina Tamoio era uma passagem necessária para todos os cidadãos ilustres que visitavam a cidade de Araraquara. Entre estes, o então Governador do Estado de São Paulo Jânio Quadros e o político Juscelino Kubstichek de Oliveira. Para tentar descrever o prestígio que tal empreendimento e seus dirigentes passaram a gozar na sociedade araraquarense, basta pensarmos que os altos lucros obtidos pela empresa, principalmente mediante subsídios recebidos por leis de proteção à produção açucareira, eram redistribuídos em atividades de cunho assistencial e cultural na cidade de Araraquara. Caires (1993) demonstra em sua tese, que à medida que aumentava o poder econômico dos Morganti, aumentava também a inserção dessa família nas atividades assistenciais e culturais da cidade. Segundo a autora, eles foram

${ }^{4}$ Quando instalados no estado de São Paulo no final do século XIX, os grupos escolares se opuseram ao modelo da escola monárquica, comumente encontrada durante o século XIX que era a escola de primeiras letras. Os grupos escolares eram o que existia de mais moderno em termos educacionais até a metade do século XX, e é importante apresentar aqui sua relevância no processo de construção da sociedade republicana para entendermos sua importância quando observados dentro de uma área rural. Estes "templos educacionais" consagraram a imagem de um sistema orgânico e racional e se legitimaram, inclusive, pelo conjunto de dispositivos materiais e simbólicos postos em visibilidade, como por exemplo, a contruço de prédios próprios para a escola compreendendo uma arquitena cora imponch e comemorações cívicas que davam publicidade à ação escolar no meio social. Para aprofundamento sobre o tema ver SOUZA (1998). responsáveis diretos pela ampliação do prédio da maternidade Gota de Leite, pela ampliação das instalações do Asilo de Mendicidade, pela construção do prédio para funcionamento do Posto de Puericultura na Vila Xavier (um dos maiores bairros na época), além, dentre outras coisas, de patrocinarem o Núcleo de Belas Artes de Araraquara. Foi assim que em 1954, a Câmara Municipal da cidade, deu a uma via pública na região central o nome do fundador da usina e patriarca da família: "Comendador Pedro Morganti".

No entanto, na década de 1960 esta família entrou num novo período de sua história. As mudanças estruturais ocorridas na economia do país, foram sentidas também pela família Morganti. A implementação de técnicas agrícolas consideradas mais modernas e a extinção do regime de colonolato em 1964, foram fatores que contribuíram significativamente para a existência de uma luta política entre usineiros e colonos. Os colonos, depois de vencidos, foram transformados em assalariados agrícolas e inclusive desapropriados de seus instrumentos de trabalho e de seus animais usados também no trabalho na terra.

Em 1961 a usina lançou um plano mais agressivo de eliminação de seu excesso de mão de obra, considerando seu atraso frente ao acelerado processo de mecanização da lavoura já instaurado. Mesmo com todas as medidas tomadas no sentido de se transformar, para acompanhar o desenvolvimento das novas técnicas modernas de produção, em 1966 este modelo já se mostrava bastante obsoleto vindo a ruir completamente em Abril de 1969, com a venda da usina para um grupo detentor de forte capital financeiro, o Grupo Silva Gordo.

Para este novo grupo empresarial, era importante não somente diminuir o quadro de funcionários, mas também desmantelar o ideário que existia entre os locais. O Grupo Silva Gordo agiu dando seqüência ao projeto de mecanização da agricultura, não sendo necessário para isso, manter aquela enorme estrutura patriarcal, de relações bastante coloniais, construída pelos Morganti. Uma das iniciativas foi persuadir os funcionários a optarem espontaneamente pelo Fundo de Garantia por Tempo de Serviço (FGTS) e pelo seu desligamento da empresa. Houve um número significativo de trabalhadores, que mesmo depois de se desligarem da usina, ainda continuaram por lá, prestando serviços temporários. Talvez não conseguissem mais se desvencilhar da relação paternalista e de pertencimento àquele lugar, herdada dos tempos dos Morganti.

A década de 1970 foi marcada pelo grande volume de ações trabalhistas. 
Em 1977 o Grupo Silva Gordo já havia imprimido na Usina Tamoio, as marcas de sua administração. Segundo Caires (1993, p.368):

Nesse quadro crítico, representado pelo não pagamento de elevados débitos fiscais para com o fisco estadual e federal, com constantes atrasos nos pagamentos dos salários dos trabalhadores e o não recolhimento do FGTS, trabalhar naquela usina passou a ser uma desventura.

No final de 1981, os funcionários da Usina Tamoio deflagraram uma greve, que mesmo contando com um número significativo de adesões, inclusive dos trabalhadores da lavoura, acabou fracassando, porque, como sugere a pesquisadora, esbarrou em mecanismos utilizados pela empresa para esvaziar o movimento e na falta de tradição de luta por parte deste grupo de trabalhadores ofuscada, inclusive, pelo peso da relações sociais fortemente enraizadas desde o período Morganti. Após a demissão por justa causa de 22 trabalhadores considerados "os cabeças" da greve, e a decretação de licença coletiva até o início de Janeiro de 1982, os trabalhadores foram desarticulados. O que não significa que a história estivesse acabada e resolvida.

Logo após a greve dos funcionários da Usina Tamoio, toda a cidade de Araraquara foi mobilizada, informada dos acontecimentos, pela Comissão de Apoio aos Trabalhadores da Usina Tamoio, grupo constituído por várias entidades de classe de Araraquara: Sindicatos, Partidos, Representantes de instituições ligadas à Igreja Católica, à Comissão de Justiça e Paz e representantes dos Trabalhadores da usina, entre outros. A Comissão arrecadou fundos e alimentos para os grevistas e demitidos e também promoveu reuniões entre o proprietário e os trabalhadores da usina.

Em Outubro de 1982 a Usina Tamoio foi paralisada com 250 a 500 mil toneladas de cana para serem moídas, fato repercutido nacionalmente. $\mathrm{Na}$ tentativa de solucionar o caso, representantes de vários órgãos sindicais, governamentais estaduais e federais, chegaram a discutir a perspectiva de desapropriação da usina pelo não cumprimento dos interesses sociais Aqui observamos uma nítida tentativa de aplicação das diretrizes oriundas do Estatuto da Terra. No entanto, o que se notou foi a vitória do discurso elitista, que amparado juridicamente, preconizava ser impossível tal processo de desapropriação, pelo fato dos trabalhadores rurais da usina serem enquadrados sindicalmente como industriários, sendo seus problemas trabalhistas de natureza urbana, não cabendo a eles uma justa reivindicação pela terra.

Em 1986, na ocasião da visita do Ministro da Reforma e Desenvolvimento Agrário - Dante de Oliveira - em Araraquara, políticos e lideranças sindicais locais solicitaram ao ministro a inclusão da Usina Tamoio no Plano Nacional de Reforma Agrária. O fato importante era que desde 1982 até aquela data, período em que a usina ficou desativada, suas terras continuaram arrendadas e plantadas por outros usineiros da região.

Segundo Caires (1993), a questão da terra apareceu atrelada à luta pelos direitos. O Sindicato dos Trabalhadores Industriários e Agrícolas de Araraquara defendia o pagamento dos direitos trabalhistas e prosseguiu acionando judicialmente o Grupo Silva Gordo, e conseguiu em Janeiro de 1983 que a justiça colocasse em leilão a Fazenda Chibarro, que havia sido oferecida pelo grupo proprietário em caução à dívida referente ao pagamento dos salários atrasados e o FGTS não recolhido dos funcionários. Após uma tentativa fracassada de leilão desta fazenda, foi decidido adjudicar a propriedade em nome do sindicato para o pagamento de tais débitos trabalhistas. A ação do sindicato, que desde o início tendia a preferir medidas conciliatórias com os proprietários da usina, a ausência de tradição de luta por parte dos trabalhadores da usina e o desgaste provocado pelo longo período de espera, fizeram com que fosse realizado um acordo conciliatório entre as partes. ${ }^{5}$

Sobre este acordo conciliatório:

[...] Ainda, para tal decisão, colaborou muito a crença de que a terra nada lhes servia sem as condições técnicas para trabalhá-la. A ilusão de que a usina pudesse vir a ser reativada, impediu que os trabalhadores mantivessem o desejo de se tornar proprietários das terras, que segundo alguns deles, representam o seu pulmão. É na Fazenda Chibarro que se encontra a represa, fonte de água para a usina e da qual ela não prescinde. Mais uma vez, parece ter prevalecido a crença de que a terra do patrão era inviolável. Parece ter pesado nesta decisão resquícios da fidelidade sentida e devida desde o período Morganti, fortemente enraizada na memória e na vida dos seus antigos trabalhadores. (Caires ,1993 p.377)

Devido a certeza de que após o acordo trabalhista, estava extinta a possibilidade dos trabalhadores assalariados rurais da usina se tornarem ${ }^{5}$ A Assembléia de liquidação do processo 466/82, foi realizada na sede do Sindicato dos Trabalhadores Industriários e Agrícolas de Araraquara em junho de 1988. 
proprietários de terras, e que as terras desapropriadas continuariam a ser arrendadas sem nenhum controle por parte dos órgãos governamentais, o Sindicato dos Empregados Rurais, com sede em Araraquara, liderado pelo sindicalista Élio Neves, iniciava uma campanha que objetivava mobilizar trabalhadores desempregados, gerando uma demanda real por terra na região.

Foi assim, que em 1989, a Fazenda Bela Vista do Chibarro foi ocupada pelos trabalhadores rurais, sendo a partir de então, destinada ao "Projeto de Reforma Agrária Assentamento Bela Vista do Chibarro". 6 A partir deste momento, aproximadamente 150 famílias oriundas de várias partes do país, orientadas pelo líder sindical Élio Neves, migraram para estas terras e deram início ao processo de demarcação e distribuição das terras. A divisão da Fazenda Bela Vista em lotes agrícolas para cada família foi feita sob a orientação do DAF (Departamento de Assuntos Fundiários), órgão do Governo do estado de São Paulo. A partir de então, os assentados passaram a cultivar aquela terra para a produção de alimentos para subsistência e para comercialização.

\section{Grupo Escolar Pedro Morganti: disseminação da cultura escrita e a formação do trabalhador rural}

O objetivo específico deste tópico é apresentar uma caracterização da escola primária estudada a partir de um diálogo com as seguintes fontes documentais: os Livros de Matrículas e os Livros do Ponto Pessoal.Apontamos, a partir da leitura e sistematização dos dados, algumas considerações sobre o desenvolvimento histórico desta instituição de ensino, abordando alguns temas que nos permitiram a leitura destas fontes documentais.

Os livros de matrículas foram instrumentos importantes para uma caracterização do corpo discente. A partir deles pudemos apresentar informações referentes à quantidade de alunos que freqüentaram esta escola no decorrer dos anos, construímos um quadro referente ao endereço dos alunos que freqüentaram a instituição, apresentamos as diferentes nacionalidades de seus pais, assim como quais foram as diferentes profissões encontradas nos registros. Nos Livros Ponto de Pessoal foram encontradas informações que nos permitiram construir uma linha do tempo cronológica e nominal dos diretores deste grupo escolar.

${ }^{6} \mathrm{O}$ trabalho de pesquisa realizado por BARONE, LA. Revolta Conquista e Solidariedade: a economia moral dos trabalhadores rurais em três tempos: Araraquara 1996 164 p. Dissertaçõo (mestrado) - Faculdade de Ciências e Letras. Universiduc

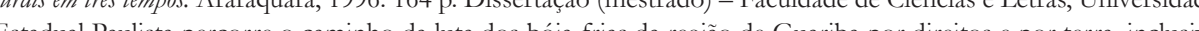
discorre heform Agrária do Assentamento Bela Vista. p. 105
Entre 1942 e 1988, pudemos observar que a escola ofereceu o ensino primário de 4 anos para meninos e meninas moradores da Fazenda Bela Vista. O quadro de matrículas permitiu uma visualização do fluxo de alunos durante o período estudado.

Quadro 1- Demonstrativo de Matriculas dos Alunos do G.E. "Comendador Pedro Morganti” 1942-1988

\begin{tabular}{|c|c|c|c|}
\hline Ano & Masculino & Feminino & Total \\
\hline 1942 & 89 & 85 & $\mathbf{1 7 4}$ \\
\hline 1945 & 146 & 136 & $\mathbf{2 8 2}$ \\
\hline 1950 & 98 & 89 & $\mathbf{1 8 7}$ \\
\hline 1955 & 127 & 102 & $\mathbf{2 2 9}$ \\
\hline 1961 & 148 & 131 & $\mathbf{2 7 9}$ \\
\hline 1965 & 119 & 125 & $\mathbf{2 4 4}$ \\
\hline 1970 & 77 & 94 & $\mathbf{1 7 1}$ \\
\hline 1975 & 33 & 37 & $\mathbf{7 0}$ \\
\hline 1980 & 16 & 21 & $\mathbf{3 7}$ \\
\hline 1985 & 14 & 03 & $\mathbf{1 7}$ \\
\hline 1986 & 09 & 05 & $\mathbf{1 4}$ \\
\hline 1987 & 06 & 05 & $\mathbf{1 1}$ \\
\hline 1988 & 04 & 07 & $\mathbf{1 1}$ \\
\hline
\end{tabular}

Fonte: Livros de Matrícula do Grupo Escolar Pedro Morganti de 1942 a $1988^{7}$

Iniciamos nossa análise pelos Livros de Matrículas, por serem substancialmente ricos em informações sobre o alunado no decorrer do tempo; e foram abundantes as informações recolhidas, que nos permitiram construir uma caracterização dos estudantes do Grupo Escolar Comendador

Livro de Matrícula "Secção Masculina" de 1942 a 1948 do Grupo Escolar da Fazenda Bela Vista, Livro de matrícula "Secção Feminina" de 1942 a 1948 do Grupo Escolar da Fazenda Bela Vista, Registro Escolar: Matrícula, Professores e Aparelhamento escolar - Modelo I - do Grupo Escolar Rural Comendador Pedro Morganti de 1949 a 1957, Livro de Matrícula dos alunos do Grupo Escolar Rural Comendador Pedro Morganti de 1961 a 1964, Livro de Matrícula das alunas do Grupo Escolar Rural Comendador Pedro Morganti de 1961 a 1964, Livro de Matrícula "Masculino" do Grupo Escolar Rural Comendador Pedro Morganti de 1965 a 1967, Livro de Matrícula "Feminino" do Grupo Escolar Rural Comendador Pedro Morganti de 1965 a 1967, Livro de Matrícula do G.E.R “Comendador Pedro Morganti” de 1968 a 1973-Feminino, Livro de Matrícula do G.E.R. "Come "Comencla Pedeção Bela Vista em Tamoio - Araraquara - de 1975 a 1984, Livro de Matrícula da 1ª Escola Mista da Secção Bel Vista em Tamoio - Araraquara - de 1975 a 1988 
Pedro Morganti de 1942 até o final da década de $1980^{8}$

No diálogo com os Livros de Matrículas, pôde-se observar o intervalo de tempo em que houve crescimentos e diminuições no número de matrículas por ano, mostrando profunda relação com o desenvolvimento econômico e social da Usina tamoio; nos momentos em que o império do açúcar estava no em ascensão e auge, observamos um crescimento substancial de $38 \%$ no número de matrículas nos três primeiros anos analisados, chegando ao ano de 1945 com 282 alunos, mantendo esta média de alunos até o início da década de 60, quando em 1961 possuía 279 matriculados. Já ao observarmos o fato de que em 1970 havia 171 matrículas registradas, apontamos uma diminuição no número de alunos matriculados por volta de $39 \%$. O que estabelece um diálogo com as mudanças ocorridas no decorrer da década de 1960, tanto no que concerne a economia do país, quanto aos seus efeitos sobre questões sócio-econômicas da Usina Tamoio.

Com o fim do império dos Morganti, a partir da venda da Usina Tamoio para o Grupo Silva Gordo, em 1969, este grupo aperfeiçoa o processo, já iniciado pelos proprietários anteriores, de implantação de um novo modelo administrativo organizacional, além da utilização de algumas máquinas agrícolas e do uso de técnicas de cultivo mais modernas.

Ainda refletindo sobre as informações oriundas dos Livros de Matrículas, no que se refere ao fluxo e refluxo de matrículas ao longo dos anos, relacionado ao contexto histórico e social em que viviam estes alunos, praticamente toda a década de 1970, foi marcada por ações trabalhistas, que culminaram em acordos com os empregados, na maioria das vezes somente vantajosos para os empregadores. As fontes indicam num curto período de 5 anos, de 70 a 75, o grupo escolar em questão, perdeu 101 alunos, ou seja, em apenas 5 anos a escola perdeu praticamente $60 \%$ do alunado que tinha no início da mesma década. O que se repete no próximo qüinqüênio. Em 1975

\footnotetext{
${ }^{8}$ Não realizamos a aferição anual dos dados, optamos por recolhê-los de cinco em cinco anos. É importante apontar que nos vimos livres em retroceder e acelerar cronologicamente, de acordo com a disposição em que os dados se apresentaram nomosta des documentos mais antigos encontrados, passamos por 1945, por entender que nestes primeiros anos de vida deste grupo escolar, seria importante diminuir o espaço de tempo de análise dos dados, para aumentar a quantidade de indícios oferecidos a esta pesquisa. Outro espaço de tempo que não foi de cinco anos, foi de 1955 a 1961. Quando voltamos a pesquisa documental para o ano de 1960, nos deparamos com somente um livro de matrícula, o livro feminino, não existindo dados referentes a Seç̧ão Masculina. Então observamos que o ano de 1961 continh estas informações completas e era melhor que o usássemos como fonte de dados; logo em seguida, fomos ao ano de 1965, diminuindo o período de nossa ańlise para quatro anos. Continumos então a partir desta data a

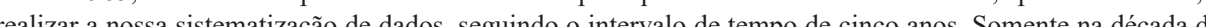
realizar a nossa sistenazizaça de danos, segnindo o intervalo de tenco ce cinco anos. Somente na década de 980, é que novamente vamos alterar o espaço de tempo para a análise dos dados; a partir de 1985 até o ano de 1988 os dados passaram a ser coletados anualmente.
}

esta instituição tinha 70 alunos matriculados e ao chegar em 1980 possuía apenas 37 deles, ou seja, no segundo qüinqüênio foi reduzida em $52 \%$ dos alunos que atendia. Percebemos então, que a quantidade decrescente de alunos está intimamente ligada às ações postas em práticas pelo novo modelo organizacional e operacional adotado na Usina tamoio durante todos os anos 70 . O enxugamento do corpo de empregados provocou o acelerado esvaziamento do corpo discente do grupo escolar pesquisado durante esta década

Os registros históricos usados neste trabalho, apontam que o Grupo Escolar Comendador Pedro Morganti esteve em funcionamento até o ano de 1988. O fato dos livros de matrículas correspondentes aos dois últimos anos, apresentarem a nomenclatura de "Livro de Matrícula da $1^{\mathrm{a}}$ e $2^{\mathrm{a}}$ Escolas Mistas", pois nestes dois últimos anos a escola funcionou como um apêndice da Escola Estadual Carlos Batista Magalhães, o que evidencia o processo acelerado de nucleação e fechamento das escolas isoladas e mistas rurais finalmente legalizado a partir do Decreto 29.499 de 05/01/1989 que dispunha sobre a política de nucleação das escolas rurais. As aulas eram ministradas no prédio do Grupo Escolar Pedro Morganti, no entanto, todo o aparelhamento técnico administrativo era feito pela escola citada, situada na cidade de Araraquara. Os 11 estudantes que permaneceram matriculados e freqüentando as aulas na Fazenda Bela Vista até o ano de 1988, eram filhos de ex-empregados da Usina Tamoio, em sua maioria, pessoas ligadas ao trabalho agrícola ou de serviços gerais, que no ano de 1989 foram incorporados ao projeto de Reforma Agrária e continuam morando no Assentamento Bela Vista até os dias de hoje.

Ao realizar esta análise das fontes documentais, foi imprescindível levar em consideração os conflitos existentes entre a relação de patrão/empregado, assim como pensar esta relação dentro de outro conflito maior, que é o existente entre modelos de desenvolvimento para a agricultura. Discorrer sobre o processo de transição de um sistema paternalista colonial para outro centrado em tecnologias modernas e aplicáveis ao campo ofereceu elementos para entender o que nos apresentou o arquivo do Grupo Escolar Pedro Morganti.

Este quadro demonstra, pelas informações recolhidas nos livros de matrículas, que esta escola primária atendeu majoritariamente a filhos de cidadãos brasileiros. A imigração italiana foi a que predominou, seguida da espanhola e japonesa. Com relação à imigração italiana e a imigração japonesa, é importante apontar que em nossa região existiam muitas fazendas de café no início do século, inclusive a própria Fazenda Bela Vista havia sido uma fazenda produtora de café. 
Quadro 2 - Nacionalidade dos Pais dos Alunos do G.E. “Comendador Pedro Morganti"(1942 - 1988).

\begin{tabular}{|l|l|l|l|l|l|l|l|l|l|}
\hline ANO & BRASIL & ITALIA & ESPANHA & JAPÂO & ALEMÃNHA & PORTUGAL & POLONIA & DESC & $\begin{array}{l}\text { Total de } \\
\text { Estrangeiros }\end{array}$ \\
\hline $\mathbf{1 9 4 2}$ & 137 & 29 & 08 & - & - & & & & 37 \\
\hline $\mathbf{1 9 4 5}$ & 234 & 24 & 19 & 03 & 02 & - & & & 48 \\
\hline $\mathbf{1 9 5 0}$ & 157 & 11 & 05 & 11 & 01 & 01 & 01 & & 30 \\
\hline $\mathbf{1 9 5 5}$ & 224 & - & - & 02 & - & 01 & 02 & & 05 \\
\hline $\mathbf{1 9 6 1}$ & 266 & - & - & - & - & - & - & 13 & - \\
\hline $\mathbf{1 9 6 5}$ & 241 & - & 03 & - & - & - & - & & 03 \\
\hline $\mathbf{1 9 7 0}$ & 171 & - & - & - & - & - & - & & - \\
\hline $\mathbf{1 9 7 5}$ & 36 & - & - & - & - & - & - & & - \\
\hline $\mathbf{1 9 8 0}$ & 37 & & & & & & & & - \\
\hline $\mathbf{1 9 8 5}$ & 17 & - & - & - & - & - & - & & - \\
\hline $\mathbf{1 9 8 6}$ & 14 & & & & & & & & - \\
\hline $\mathbf{1 9 8 7}$ & 11 & - & - & - & - & - & - & & - \\
\hline $\mathbf{1 9 8 8}$ & 11 & & & & & & & & - \\
\hline TOTAL & 1.556 & 64 & 35 & 16 & 03 & 02 & 03 & 13 & 123 \\
\hline
\end{tabular}

Fonte: Livros de Matrícula do Grupo Escolar Pedro Morganti de 1942 a 1988.

O que explicaria o contexto de predomínio de imigração destes povos, pois é fato o êxodo destas populações para o trabalho agrícola no Brasil, tendo em vista a necessidade de uma substituição emergencial para o trabalho escravo.

Sobre a profissão dos pais, pudemos verificar que no Grupo Escolar Pedro Morganti, os filhos dos lavradores sempre foram maioria dos alunos matriculados Em todo o período demarcado, a quantidade de matrículas dos filhos cujos pais se declararam lavradores foi superior a dos que se declararam desempenhando outras profissões. Observamos que a nomenclatura referente ao trabalhador da terra foi se alterando no decorrer da amostragem. Em 1942 o número de pais de alunos cuja profissão era registrada como colonos era de 139 pessoas, já três anos depois, os registros apontaram 226 lavradores, então registrados no livro de matrícula com esta denominação. Houve a mudança de nomenclatura, assim como o aumento significativo no número de trabalhadores ligados diretamente ao trabalho manual agrícola. Em 1950 aparecem além de 25 lavradores, mais 86 pessoas registradas nos livros de matrículas com a terminologia de "camaradas", totalizando 111 pessoas apontadas como ligadas ao trabalho agrícola. Cinco anos depois, os dados apontam o início de um novo crescimento na matrícula de filhos de agricultores: Em 1955: 171 matrículas; em 1961: 225 matrículas. Percebemos que o período que compreendeu o apogeu da produção açucareira da Usina Tamoio, também foi o período em que mais o apelo pela escolarização esteve presente entre os filhos dos trabalhadores rurais.

Estes dados podem contribuir para uma maior compreensão da cultura local. O colono como aparece nos primeiros registros, era um trabalhador que possuía muito mais raízes com a terra e com o local, o fato de ter sido substituído pelo lavrador e depois pelo camarada, já nos ofereceu um possível sinal de que estava em curso uma mudança na estrutura de trabalho dentro daquele espaço da usina. O colono possuía muito mais ligação com a terra, morava nela e criava raízes, entregava seu filho para ser batizado pelo usineiro, enfim, sua relação de trabalho era perpassada por valores e obrigações morais para com seu empregador, que além de lhe oferecer trabalho também lhe oferecia casa e segurança. Sua substituição aponta para um processo de modernização imposto ao campo. Um afrouxamento das relações de trabalho, visto que o camarada era um trabalhador rural com um caráter mais itinerante, um prestador de serviços.

$\mathrm{O}$ crescimento no número de matrículas dos filhos de trabalhadores agrícolas justifica o sentido da existência e a função social deste grupo escolar. No ano de 1970 apareceu nos registros a matrícula de 142 crianças filhas de lavradores, e em seguida este número caiu para apenas $56 \mathrm{em}$ 1975. Estes cinco anos marcaram o início do processo de modernização imposto pelos novos proprietários da Usina Tamoio, processo de mecanizar a agricultura, substituindo o homem pela máquina, e num sentido mais abstrato, um processo de mudança da própria sociedade brasileira, que tentava sair do atraso, que era reflexo do nosso antigo sistema colonial, e adentrar no mundo moderno, no novo modelo de alta competitividade econômica e um novo delineamento social. Era necessário desconstruir todo o emaranhado de relações sociais de cunho paternalista e colonial e introduzir as novas ideias, que eram atreladas ao novo modelo de desenvolvimento que se queria para a sociedade brasileira.

Houve diminuição no número total de matrículas a partir do fim da década de 60 e início da década de 70, o que comprova que os cortes de empregados se deram de uma maneira geral, no entanto, como representavam a maioria 
das matrículas, o corte no número de lavradores foi o que mais se fez sentir, afinal, seus filhos representavam quase a totalidade dos alunos desta escola primária rural. De um total de 21 lavradores com filhos nesta instituição em 1980, somente 9 permaneceram na fazenda, depois da tramitação da greve e dos acordos firmados, sendo incorporados em 1989 ao Projeto de Reforma Agrária do Governo Federal.

Quadro 3 - Relação Nominal dos(as) Diretores(as) do Grupo Escolar Comendador Pedro Morganti de 1942 a 1975.

\begin{tabular}{|l|l|l|l|}
\hline NOME & FUNÇÃO/CARGO & PERÍODO & PERMANÊNCIA \\
\hline Amêndola Silva & Diretora Interina & $04 / 1942$ a 05/1942 & 02 meses \\
\hline Paulo Ferrari Massaro & Diretor Efetivo & $06 / 1942$ a 04/1943 & 10 meses \\
\hline Iracema Gonçalves Gazi & Diretora Efetiva & $05 / 1943$ a 06/1944 & 13 meses \\
\hline Heledina de Oliveira & Diretora Interina & $07 / 1944$ & 01 mês \\
\hline Eros Benfatti & Diretora Estagiária & $08 / 1944$ a 12/1946 & 28 meses \\
\hline Zoe Tavares & Diretora Substituta & $01 / 1947$ a 08/1947 & 08 meses \\
\hline João Loureiro Miranda & Diretor Efetivo & $09 / 1947$ a 10/1947 & 02 meses \\
\hline Zoe Tavares & Diretora Substituta & $11 / 1947$ a 02/1948 & 04 meses \\
\hline Maria Cruz & Diretora Substituta & $03 / 1948$ a 06/1948 & 04 meses \\
\hline Geraldo Schettini Sobrinho & Diretor Interino & $07 / 1948$ a 09/1948 & 03 meses \\
\hline José Armando Furlani & Diretor Efetivo & $10 / 1948$ a 12/1949 & 14 meses \\
\hline Missiota Reis Pitta & Diretora Substituta & $03 / 1950$ a 07/1950 & 05 meses \\
\hline Geraldo Schettini Sobrinho & Diretor Interino & $08 / 1950$ a 10/1950 & 03 meses \\
\hline Dalmo Homem de Melo & Diretor Efetivo & $11 / 1950$ a 08/1954 & 45 meses \\
\hline Lúcio Ferraz de Arruda & Diretor Interino & $09 / 1954$ a 09/1956 & 24 meses \\
\hline Amadeu Cosentino & Diretor Efetivo & $10 / 1956$ a 03/1960 & 41 meses \\
\hline João Levy Junior & Diretor Interino & $04 / 1960$ a 07/1961 & 15 meses \\
\hline Jayme de Arruda Dias & Diretor Interino & $08 / 1961$ a 09/1961 & 02 meses \\
\hline Dimas de Maio Freitas & Diretor Efetivo & $10 / 1961$ a 04/1965 & 42 meses \\
\hline Adair Garcia Freitas & Diretora Substituta & $05 / 1965$ a 02/1966 & 10 meses \\
\hline Dinah Aparecida Bechara & Diretora Substituta & $03 / 1966$ a 12/1966 & 09 meses \\
\hline Marisa Teresa Garrido & Diretora Substituta & $03 / 1967$ a 07/1967 & 04 meses \\
\hline Antonio Ruy Cardoso & Diretor Efetivo & $08 / 1967$ a 05/1969 & 21 meses \\
\hline Neusa Ap. Ferreira Silva & Diretora Interina & $06 / 1969$ a 02/1970 & 08 meses \\
\hline Lúcia Rached & Diretora Substituta & $03 / 1970$ a 02/1974 & 47 meses \\
\hline Aracy Dias Mendes & Diretora Substituta & $03 / 1974$ a 02/1975 & 11 meses \\
\hline & & & \\
\hline
\end{tabular}

Fonte: Livros Ponto do Arquivo da EMEF Prof. Hermínio Pagôtto, antigo Grupo Escolar Comendador Pedro Morganti.
Entendendo que a experiência dos sujeitos envolvidos na história deste grupo escolar contribuiu para a formação de sua cultura escolar, foi necessário também que fizéssemos uma apresentação dos diretores que atuaram nesta instituição de ensino. Esta caracterização serve para colocar em relevo os importantes atores que conduziram este palco educacional. Apresentá-los pareceu-nos uma importante contribuição aos registros históricos. Para tanto foi necessário que nos debruçássemos sobre os Livros do Ponto Pessoal que, por se apresentarem dando conta de praticamente todo o período de estudo desta pesquisa, puderam nos oferecer dados que permitiram uma identificação mais completa.

Durante a década de 1940 os registros do Livro Ponto informam que 13 profissionais do magistério exerceram a direção desta instituição de ensino. Vimos que houve uma grande rotatividade de permanência no cargo sendo que vários destes profissionais ocuparam a função em caráter efetivo permanecendo pouco tempo nele. $\mathrm{O}$ que nos parece interessante apresentar é que a diretora Eros Benfatti que ocupava o cargo de diretora estagiária foi a que mais tempo permaneceu naquela década exercendo a função de diretora durante um período de 28 meses. Os demais exerceram a função por um período inferior ou um pouco maior do que um ano.

A década de 1950 apresentou uma considerável estabilidade no que concerne ao tempo de permanência de pessoas no cargo da direção da escola. Logo no início desta década, o sr. Dalmo Homem de Melo permaneceu como diretor por um período de 45 meses, o que corresponde a um período de aproximadamente quatro anos sem deixar o cargo. Em seguida, vimos que o sr. Lúcio Ferraz de Arruda assumiu tal vaga e nela ficou por um período de dois anos, sendo sucedido pelo sr. Amadeu Cosentino que encerrou a década de 1950 ficando 41 meses no cargo. Percebemos então, que a década de 1950 apresentou uma maior estabilidade na ocupação da direção do grupo escolar com relação a década anterior tendo somente três diretores diferentes neste período.

Os anos correspondentes a década de 1960 voltam a ter um fracionamento na ocupação do cargo de diretor de escola neste grupo escolar. Enxergamos que somente o sr. Dimas de Maio Freitas se manteve por um período relativamente extenso ocupando a direção da escola 42 meses, ou seja, por três anos e meio, sendo seguido pelo sr. Antonio Ruy Cardoso que no cargo permaneceu por pouco menos de dois anos. Os demais ocupantes desta função durante esta década não permaneceram nela por mais de um ano consecutivo. 
Embora tenhamos somente os registros referentes a metade dos anos da década de 1970, conferimos que neste período de tempo a sra. Lúcia Rached ocupou o cargo de diretora do grupo escolar por praticamente quatro anos, o que vem demonstrar uma certa estabilidade no preenchimento da vaga neste período.

O que tentamos demonstrar com esses dados foi o fato de que as permanências e as rupturas podem contribuir para uma efetiva visualização do que aqui denominamos de caracterização deste grupo escolar. Intuímos que as mudanças no corpo diretivo da escola afetaram ao longo da história diretamente sua dinâmica de funcionamento, visto que o afinamento das relações interpessoais entre diretor e professores, por exemplo, levavam um tempo para serem construídas e fortalecidas. Assim, quando havia a substituição da parte diretiva provavelmente todos tinham que se readaptar aos novos hábitos da nova pessoa que passava a ocupar tal função, o que pode significar que tais mudanças na equipe escolar prejudicaram o seu funcionamento ao longo dos anos. Como foram poucos aqueles que permaneceram na direção da instituição por um longo período de tempo, foram muitos os que por ali passaram permanecendo um período curto na função, não podendo desta forma contribuir de forma sistematizada para a efetivação de algum projeto educativo, seja os de cunho ruralista, ou mesmo os de cunho estritamente pedagógico.

O diálogo com os Livros de matrículas e com os Livros do Ponto foi importante para a realização da tarefa de construir a caracterização do grupo escolar estudado, no entanto, esses documentos não deram conta de apresentar indícios sobre a dinâmica pedagógica da instituição. Para tal, nos debruçaremos a seguir sobre as Atas das Reuniões Pedagógicas, no intuito de mergulhar de uma maneira mais profunda no cotidiano pedagógico desta instituição de ensino primário.

\section{Vestígios da Cultura Escolar na mesa de reuniões pedagógicas}

Os livros de atas das reuniões pedagógicas foram documentos importantes que nos forneceram indícios significativos da cultura escolar do Grupo Escolar Comendador Pedro Morganti. Foram analisados os quatro volumes encontrados no acervo da instituição, que deram conta de um período de 1950 à 1971, totalizando 159 reuniões pedagógicas. No último volume desta coleção, no entanto, há o registro de uma reunião pedagógica realizada no ano de 1975. Fica aparente que este período não corresponde ao período completo de estudo proposto pela pesquisa, todavia, os registros dessas atas permitiram apreender aspectos significativos da cultura escolar desta instituição de ensino primário.

Ocorrências de Reuniões Pedagógicas do G.E. "Comendador Pedro Morganti 1950/ 1975

Não podemos afirmar entretanto, que os 4 volumes encontrados de Livros de Atas de Reuniões Pedagógicas correspondem ao histórico completo das reuniões pedagógicas desta instituição de ensino primário, visto que há uma lacuna nas informações das fontes documentais encontradas. No entanto, o período que corresponde às reuniões pedagógicas registradas nas atas encontradas, possibilitaram uma reflexão em torno de duas décadas em que aconteceram importantes mudanças no cenário rural brasileiro.

Pareceu-nos importante apresentar algumas informações sobre alguns aspectos gerais das atas de reuniões pedagógicas. Elas estão registradas em quatro livros próprios, identificados para este fim em suas capas. Todas as reuniões foram escrituradas seguindo uma ordem em que primeiramente eram tratadas questões administrativas e em seguida tratadas questões técnicas, ou de orientações pedagógicas propriamente ditas.

A primeira parte das reuniões, de cunho administrativo, era composta pela leitura e pela aprovação da ata da reunião anterior, seguida da leitura de informes dos mais variados possíveis. circulares, comunicados, portarias de dispensa, de remoção, afastamento, licenças, abonos, atestados e etc. Havia nessa primeira parte o registro das recomendações, que eram bastante objetivas para o funcionamento da unidade escolar. A segunda parte das reuniões pedagógicas era de caráter mais técnico e visava oferecer apoio pedagógico ao corpo docente. Eram aulas ministradas pelo diretor, pelo inspetor de ensino ou pelos professores previamente escolhidos sobre os mais variados temas, todavia, todos os temas estavam ligados aos conteúdos a serem ministrados ou aos métodos de ensino a serem apreendidos e executados. Estes momentos pré-planejados, consistiam em leituras de textos ou trabalhos científicos, cujos objetivos eram contribuir para uma melhoria no processo de ensino-aprendizagem.

As recomendações tinham um caráter disciplinador e prescritivo do que deveria ser cumprido pelo corpo docente e discente. Discorriam sobre a necessidade de disciplinar o comportamento escolar do alunado, assim 
como disciplinar e normatizar a rotina docente.

Selecionamos para este texto alguns aspectos da cultura escolar, apreendidos pelos indícios provenientes da leitura das atas de reuniões pedagógicas referentes às práticas de educação rural. ${ }^{9}$

\section{Prática de Educação Rural}

Sobre as aulas de ruralismo, os documentos demonstraram que havia um significativo esforço por parte da direção do grupo escolar para que efetivamente fossem realizadas. Durante as duas décadas de reuniões registradas em atas, havia um nítido interesse dentro da unidade escolar para que as aulas teóricas sobre ruralismo fossem desenvolvidas e seus conhecimentos exigidos nas avaliações finais. Também as aulas práticas aparecem nos registros, quando havia recomendações acerca do comportamento dos alunos nos espaços externos, quando havia informes sobre a aquisição de materiais para que tais aulas fossem realizadas, quando no início do ano letivo havia a organização do horário de realização de tais atividades de estudos agrícolas nos espaços externos como a horta, o pomar ou o aviário.

As atividades de ensino referentes ao ruralismo pedagógico ${ }^{10}$ estavam ligadas diretamente ao ensino de técnicas simples de trabalho no meio rural. Montar um canteiro, desde o processo de preparo da terra com insumos orgânicos, passando pela semeadura até a colheita, por exemplo, eram ensinamentos escolares ministrados sobre a nomenclatura de ruralismo. Havia a intenção de racionalizar a prática do camponês e introduzir nela técnicas de melhoria da produção, além de uma objetiva orientação sobre a higienização do modo de vida daqueles que habitavam a zona rural, enfim, o

\footnotetext{
Selecionamos para análise neste texto as práticas de educação rural, no entanto, em TEIXEIRA (2010) são apresentadas análises de outros aspectos da cultura escolar apreendidos pelos indícios provenientes da leitura das atas de reuniões pedarógicas tais como a normatização do trabalho docente, a disciplina dos alunos, e as crmpanhas comemoraçõe

Ruralismo Pedagógico refere-se a uma ideologia dominante na primeira metade do século XX a partir de um contingente de intelectuais e educadores que se intitulou ruralista, dando origem ao termo ruralismo pedagógico. Esse grupo colocava em destaque os problemas que envolviam a educação rural no Brasil, estabelecendo relações como contexto sócio-político-econômico do país. Entre os principais representantes desse grupo estavam Alberto Torres,Carneiro Leão, Sud Mennucci e Noemia Cruz. Eles criticavam o modelo único de escola primária existente no estado, concebido nos moldes de uma escola citadina alicerçada nos valores e na cultura urbana. Essa escola não servia ao homem do campo. Inadequada totalmente ao meio concorria, tão somente, para o êxodo rural. Dessa maneira, eles viam na criacĩo da Escola Rural a possibilidade de fixação do homem no campo.

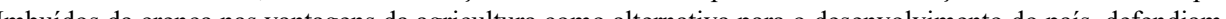
for formação de professores para a educação rural, programas de ensino apropriados às necessidades e interesses da população do campo e a ampliação das finalidades sociais da escola para esse meio. (SOUZA, 2009, p.150)
}

que parecia ser necessário que os "hábitos da sociedade moderna" também se fizessem presentes entre a população do campo.

As décadas de 1940 e 1950 foram marcadas por uma multiplicidade de projetos e programas para a educação rural. Os programas que se destacaram na década de 40 eram tanto de responsabilidade do Ministério da Agricultura, quanto dos Ministérios da Educação e da Saúde. Estes programas foram instituídos a partir do acordo dos governos brasileiro e norte-americano, quando foi instituída a Comissão Brasileiro-Americana de Educação das Populações Rurais (CBAR), embrionária da Associação Brasileira de Assistência Técnica e Extensão Rural (ABCAR), que foi criada em 21 de junho de 1956 (CALAZANS, 1993 p. 23-24).

O objetivo da Comissão e mais tarde da Associação era implantar projetos educacionais na zona rural, bem como desenvolver as comunidades desse meio através da criação de centros de treinamento, realização de semanas ruralistas e também da criação e implantação dos chamados Clubes Agrícolas e dos Conselhos Comunitários Rurais, assim como também estava incumbida de coordenar programas de extensão e captar recursos técnicos e financeiros (LEITE, 1999).

Ao consultar a Coleção das Leis e Decretos do Estado de São Paulo, verificamos que a lei $\mathrm{n}^{\mathrm{o}} 2.648$ de 17 de Janeiro de 1936 instituiu na Secretaria de Agricultura o Departamento dos Clubes de Trabalho, que visava desenvolver trabalhos agrícolas nas escolas primárias do estado. A partir da leitura deste ordenamento jurídico, evidenciamos a intenção do Estado de que fossem desenvolvidos os trabalhos manuais agrícolas dentro de um programa educativo.

Por conseguinte, o decreto 8.927 de 19 de Janeiro de 1938 de autoria do Interventor Federal no Estado de São Paulo o Dr. José Joaquim Cardozo de Mello instituiu nos estabelecimentos de ensino primário, a juízo das Diretorias de Ensino os Clubes de Trabalho. Este decreto transferia da Secretaria de Agricultura para a Secretaria da Educação o gerenciamento destes Clubes. Este decreto se apresentou então, como normatizador de uma política pública educacional que considerava como dever do Estado cultivar na juventude o gosto pelos trabalhos manuais e especialmente pelas atividades de natureza agrícola. Este documento preconizava que a Diretoria de Ensino deveria editar uma publicação periódica destinada a orientar os professores primários rurais em sua ação educativa e na organização dos Clubes de Trabalho. Foram os Clubes de Trabalho criados neste período 
que foram os embriões daqueles que mais tarde seriam denominados os Clubes Agrícolas.

Ao relacionar tais informações às fontes documentais levantadas durante esta pesquisa, observamos a existência de registros referentes ao Clube Agrícola (ver Quadro 5) nesta instituição de ensino de 1954 a 1967. Foi possível pelas Atas de Reuniões Pedagógicas analisadas, encontrar elementos que comprovassem as diversas orientações acerca da implantação deste projeto de extensão rural, e de atividades ligadas à formação voltada ao homem do campo, através de trabalhos manuais agrícolas.

No trecho da Ata da Reunião pedagógica presidida pela sra. diretora Missiota Reis Pita, há a seguinte descrição:

De acordo com o Programa de Extensão Rural, publicado no Diário Oficial de 24/02/1949, os professores deverão administrar lições práticas e teóricas sobre atividades agrícolas. ${ }^{11}$

E continua a diretora na mesma ata deste dia, se referindo as provas mensais a serem realizadas em todos os sábados do mês na instituição:

[...] ficando para o quarto sábado do mês a prova referente a parte teórica do ensino rural. ${ }^{12}$

Outros momentos parecem importantes para ilustrar a relação de apropriação que sofre o ordenamento jurídico dentro da cultura escolar:

Sobre o Programa Rural, a diretora pediu que iniciássemos e praticássemos os ensinamentos que nos são exigidos, o mais breve possível. (...) Sobre isso o professor Evangelista pediu a palavra e disse que estas atividades estavam a cargo dos alunos responsáveis pela conservação e embelezamento de todo o terreno do grupo escolar. ${ }^{13}$

Sobre o Ensino Rural, os professores deverão falar sobre insistentemente, a fim de despertar na criança o amor pela terra e

\footnotetext{
Ata da Reunião Pedagógica realizada no dia 25 de Março de 1950. Livro de Atas das Reuniões Pedagógicas do Grupo escolar Pedro Morganti de 1950 a 1957. Arquivo da EMEF do Campo Professor Hermínio Pagôtto.

${ }^{12}$ Grupo

13Ata da Reunião Pedagógica realizada no dia 29 de Abril de 1950. Livro de Atas das Reuniões Pedagóóças do Grupo escolar Pedro Morganti de 1950 a 1957. Arquivo da EMEF do Campo Professor Hermínio Pagôtto.
}

acabar com a má vontade pelos trabalhos agrícolas. ${ }^{14}$

(...) e mais uma vez a diretora pediu aos professores que se apressem em apresentar um álbum, contendo os melhores trabalhos sobre ensinamentos rurais. ${ }^{15}$

Podemos perceber a insistência da direção da referida escola em colocar em prática as orientações recebidas acerca do Programa Rural, pois durante o primeiro semestre de 1950 este assunto esteve na pauta em todas as reuniões. E a indicação repetitiva "mais uma vez", sugeriu que a diretora já havia cobrado uma atitude prática em reuniões ou conversas anteriores com seus subalternos. E para ilustrar ainda mais o caráter institucional destas recomendações, de como elas eram orientadas e conduzidas pela Diretoria de Ensino, durante o segundo semestre deste mesmo ano, na ocasião da visita do Inspetor de Ensino a este Grupo Escolar, ele fez a solicitação de que:

[...] os professores insistissem no ensino para o aprendizado do que as crianças terão que usar e atuar na vida, prática agrícola, linguagem oral e escrita e leitura, deixando as outras em segundo plano. ${ }^{16}$

Com relação às políticas publicas para a educação do meio rural, no Estado de São Paulo, havia prescrições legais a serem cumpridas dentro dos Programas de Ensino das escolas rurais. O Decreto $N^{\circ} 17.698$, de 26 de novembro de 1947, no Capítulo I, em sua Secção IV ${ }^{17}$, que trata da Assistência Técnica do ensino Rural, no artigo 41 diz explicitamente que Assistência Técnica do Ensino Rural tinha por fim orientar, centralizar e coordenar todas as atividades ruralistas no ensino primário e normal do Estado, além de elaborar programas especiais para o ensino primário, rural e normal e registrar e incentivar as iniciativas desses e de outros estabelecimentos de ensino que visem despertar na infância ou na juventude $\mathrm{o}$ amor pelas coisas da terra e o interesse pelas práticas agrícolas.

No ano de 1948 foi criada a Associação de Crédito e Assistência Rural,

\footnotetext{
${ }^{4}$ Ata da Reunião Pedagógica realizada no dia 13 de Maio de 1950. Livro de Atas das Reuniões Pedagógicas do Grupo escolar Pedro Morganti de 1950 a 1957. Arquivo da EMEF do Campo Professor Hermínio Pagôtto.

${ }^{5}$ Ata da Reunião Pedarógica realizada no dia 10 de junho de 1950. Livro de Atas das Reuniões Pedagógicas do Grupo escolar Pedro Morganti de 1950 a 1957. Arquivo da EMEF do Campo Professor Hermínio Pagôtto.

${ }^{16}$ Ata da Reunião Pedagógica realizada no dia 19 de Agosto de 1950. Livro de Atas das Reuniões Pedagógicas do Grupo escolar Pedro Morganti de 1950 a 1957. Arquivo da EMEF do Campo Professor Hermínio Pagôtto. ${ }^{7}$ Essa legislação encontra-se na Coleção de Leis e Decretos do Estado de São Paulo.
} 
financiada pela "International Association for Economic Development" e que mais tarde veio a se chamar EMATER. Esta seria a precursora da Associação Brasileira de Assistência Técnica e Extensão Rural (ABCAR), criada em 1956 (Leite, 1999). Esta associação foi financiada principalmente por organizações ligadas as governo, ao capital monopolista norte americano e a organismos internacionais que visavam a expansão de mercado no Brasil, vendendo uma visão romantizada da extensão rural (Calazans, 1993). Este Programa de Extensão Rural, iniciado no término da década de 1940 e intensificado durante a década de 50 , tratava-se de um programa de caráter essencialmente paternalista em que, segundo Leite (1999), o trabalhador rural brasileiro era representado como um indivíduo carente que demandava proteção e assistência, desprovido de valores, de sistematização de trabalho ou mesmo incapacitado para tarefas socialmente significativas. Desta forma, ficavam novamente submetidos à vontade dos grupos dominantes.

Simultaneamente ao sistema formal, a estrutura física da escola também passou a compor o quadro do programa, sendo lançado um projeto em que a educação para o desenvolvimento comunitário assume um outro enfoque bastante diferenciado daquele da escola tradicional. Era essencialmente um programa pré-fabricado que desconsiderava a educação formal existente até então (Leite, 1999). O que aparece fortemente na colocação do inspetor de ensino apontado há pouco neste texto.

No início da década de 1950, foi criada a Campanha Nacional de Educação Rural (CNER), que segundo a reflexão de Leite (1999), limitou-se a repetir fórmulas tradicionais de dominação, uma vez que ela não trouxe à tona, em suas discussões, os mecanismos verdadeiros da problemática rural. Para o autor, a modernização do campo nada mais era do que a internacionalização da economia brasileira aos interesses monopolistas e sua visão educativa desconsiderava as contradições naturais dos grupos campesinos.

Toda a discussão sobre uma formação escolar com caráter limitado aos usos práticos deste conhecimento se encontra acessível para consulta ao mergulharmos nas atas de reuniões pedagógicas, pois nelas, além das prescrições exigidas, aparecem as relutâncias e as assimilações pessoais do corpo docente, incumbido de colocar em prática tais programas. Numa destas reuniões, por ocasião de os professores não estarem se esforçando em aplicar tais conhecimentos exigidos pelo Programa Rural, o diretor Dalmo Homem de Melo Braga, notificava que:

E se os senhores professores ainda relutavam em ministrar ensinamentos rurais, agora serão estimulados pelo bolso. ${ }^{18}$

$\mathrm{O}$ diretor estava se referindo ao fato que nesta reunião, foi lido um Comunicado da Assistência Técnica do Ensino Rural, direcionado aos diretores e professores que pretendessem receber a gratificação mensal a titulo de desdobramento, um adicional no salário, para aqueles que se dispusessem a aumentar sua carga horária com alunos, em virtude de participar do Programa Rural. Ainda segundo informações desta ata de reunião, todas as classes da escola tinham que se ocupar com duas horas semanais de atividades rurais, além do fato de que o Assistente Técnico Rural, pretendia transformar este grupo escolar em modelo. Já teria ele, inclusive, intercedido junto ao Comendador Hélio Morganti para que fossem construídos: um aviário e um apiário nas dependências do grupo escolar, e que estes empreendimentos, após construídos, teriam toda assistência técnica necessária por parte do governo.

Em 18 de setembro do ano seguinte, há o registro em ata de que o diretor da escola, Prof $f^{\circ}$ Lúcio Ferraz de Arruda:

Requereu ao Secretário de Educação, por intermédio da Assistência Técnica do Ensino Rural, o desdobramento do ensino prático rural, a contar da data de $01 / 04 / 54$, bem como o despacho do pagamento. ${ }^{19}$

Tal fato nos mostra que realmente foi incorporado ao Programa de Ensino da escola, o ensino prático rural tal qual havia sido preconizado com adicional de vencimentos em lei, um ano antes, pois segundo a ata, o pedido de recebimento de vencimento referente a participação no programa era retroativo ao primeiro dia do mês de abril do corrente ano. Data também deste ano a criação do Clube Agrícola, o que nos permite também pensálo como uma iniciativa tomada a partir das orientações do Programa de Extensão Rural.

É importante o fato de que as atas trazem um indicador sinalizando que a comunidade estava informada sobre tais projetos diferenciados dentro do espaço escolar. Pudemos perceber durante a leitura das atas que havia a necessidade de se publicar os melhores trabalhos sobre os assuntos agrícolas produzidos pelo grupo escolar na Revista Mensal da Tamoio. Esta revista

\footnotetext{
Ata da Reunião Pedagógica realizada no dia 11 de Abril de 1953. Livro de Atas das Reuniões Pedagógicas do Grupo escolar Pedro Morganti de 1950 a 1957. Arquivo da EMEF do Campo Professor Hermínio Pagôtto

${ }^{19}$ Ata da Reunião Pedagógica realizada no dia 18 de Setembro de 1954. Livro de Atas das Reuniões Pedagógicas do Grupo escolar Pedro Morganti de 1950 a 1957. Arquivo da EMEF do Campo Professor Hermínio Pagôtto
} 
circulava em todas as secções da usina e também nos círculos letrados da cidade de Araraquara.

O senhor professor Geraldo Schitini Sobrinho foi sorteado para elaborar uma tese referente aos assuntos agrícolas. Esta deverá ser lida na próxima reunião pedagógica e publicada na Revista Mensal da Tamoio. ${ }^{20}$

Os melhores trabalhos sobre ruralismo deverão ser publicados na Revista Mensal da Tamoio, e os alunos deverão assinar o livro de ouro pelo mérito. ${ }^{21}$

Os professores não devem se esquecer de que seus melhores trabalhos sobre a horta, jardinagem, higiene rural devem ser entregues a direção para que sejam encaminhados à Assistência Técnica Rural, sob os cuidados da Diretoria de Ensino de Araraquara e encaminhados a revista mensal da Tamoio. ${ }^{22}$

O sr. Dimas de Maio Freitas, diretor deste grupo escolar, tem o prazer de relatar que ficou muito satisfeito com o fato de que os melhores trabalhos sobre ruralismo desenvolvidos nesta escola, foram selecionados pela revista mensal da Tamoio para fazerem parte do acervo da Biblioteca Pública de Araraquara, servindo de alicerce para o trabalho de outras escolas interessadas. ${ }^{23}$

O interesse em apontar tais registros, se deve ao fato de serem expressivos, no sentido de oferecerem indícios de que havia um conhecimento público sobre as atividades diferenciadas de ruralismo do Grupo Escolar Pedro Morganti, tanto dentro dos limites da usina quanto na cidade de Araraquara. Da maneira como estão, os registros indicam que a direção da escola impunha a necessidade de que os trabalhos fossem encaminhados para publicação. Estas publicações nos pareceram variadas, desde relatórios

\footnotetext{
${ }^{20}$ Ata da Reunião Pedagógica realizada no dia 25 de Março de 1950. Livro de Atas das Reuniões Pedagógicas do Grupo escolar Pedro Morganti de 1950 a 1957. Arquivo da EMEF do Campo Professor Hermínio Pagôtto ${ }^{21}$ Ata da Reunião Pedagógica realizada no dia 19 de Setembro de 1955. Livro de Atas das Reuniões Pedagógicas do Grupo escolar Pedro Morganti de 1950 a 1957. Arquivo da EMEF do Campo Professor Hermínio Pagôtto

${ }^{22}$ Ata da Reunião Pedagógica realizada no dia 20 de Agosto de 1960. Livro de Atas das Reuniões Pedagógicas do Grupo escolar Pedro Morganti de 1957 a 1962. Arquivo da EMEF do Campo Professor Hermínio Pagôtto

${ }^{23}$ Ata da Reunião Pedagógica realizada no dia 14 de Abril de 1962. Livro de Atas das Reuniões Pedagógicas do Grupo escolar Pedro Morganti de 1962 a 1966. Arquivo da EMEF do Campo Professor Hermínio Pagôtto
}

sobre a criação e manutenção de hortas, cartazes sobre higiene no meio rural, até uma tese mais elaborada apresentada por algum professor sobre $\mathrm{o}$ assunto do ruralismo.

$\mathrm{O}$ que nos pareceu foi que era no diferencial destas atividades que este grupo escolar tinha visibilidade dentro do meio social em que estava inserido. Não há registros nas atas de que outras atividades escolares que não as relacionadas ao ruralismo fossem indicadas para serem publicadas em revistas ou encaminhadas a Diretoria de Ensino, o que evidencia o fato de que eram justamente estas atividades teóricas e práticas voltadas para o meio rural, que justificavam o valor social deste grupo escolar tanto para os superiores envolvidos com educação dentro da estrutura estatal burocrática quanto para os proprietários ou pessoas que ocupavam cargos importantes dentro da usina Tamoio.

No entanto para este trabalho não nos foi possível entrar em contato com o material referente as tais publicações, o que nos impediu de se aprofundar nesta discussão para perceber se eram direcionadas somente ao público letrado voltado para a área de educação, ou se tinham maior abrangência, englobando também os trabalhadores rurais.

A leitura mais atenta das atas pôde evidenciar que, na medida em que esse grupo escolar se destacava pelas suas atividades diferenciadas relacionadas aos trabalhos agrícolas, essas atividades se tornaram exigências prioritárias em detrimento dos trabalhos manuais relacionados as outras áreas como a carpintaria ou serralheria, por exemplo. Pareceu-nos que foi na especificidade de suas práticas escolares diferenciadas que a instituição se destacou historicamente. E acreditamos que essas práticas de elaboração de trabalhos manuais e também de práticas agrícolas se apresentaram de maneira convincente como importantes aspectos constitutivos da cultura escolar do Grupo Escolar Comendador Pedro Morganti.

\section{Considerações Finais}

Acreditamos que com essa pesquisa, conseguimos reconstruir fragmentos históricos de uma instituição educativa localizada no meio rural do interior do Estado de São Paulo, contribuindo para os estudos em história da educação, especificamente para os voltados aos estudos dos grupos escolares rurais, de que tão pouco temos informações, dado o desinteresse por seu estudo ou a precariedade na obtenção de fontes de pesquisa.

No presente trabalho optamos por reconstruir a história do Grupo Escolar Rural Comendador Pedro Morganti. Tentamos estabelecer ao longo do 
trabalho uma reflexão acerca do olhar historiográfico, que tentou apontar nas lutas, nos conflitos, nas experiências humanas em exercício contínuo de funções institucionalizadas, um espaço promissor para a construção de uma cultura escolar. Ao utilizar essa lente na tentativa de reconstituir a história do grupo escolar, oferecemos subsídios para a formação de uma cultura escolar constituída pela experiência humana dos que viveram no espaço e no tempo pesquisado.

As práticas escolares que registramos como permanentes, foram forjadas na possibilidade do agir, da intervenção humana sobre as determinações objetivas do que foi prescrito e puderam ser rastreadas através das fontes documentais que tivemos acesso. Demonstrarmos as continuidades existentes, com a intenção de comprovar o fato de que as possíveis modificações no interior das culturas escolares, não são passíveis de interrupções bruscas, justamente por que precisam ser construídas nas experiências e nas práticas escolares. Desviamos nosso olhar para o que permaneceu constante no decorrer do tempo, para o que conseguiu sobreviver frente às diversas mudanças e transformações educacionais a que foi submetida essa instituição escolar. As atas de reuniões pedagógicas, utilizadas como fontes documentais foram o lócus de reinterpretação e reconfiguração das leis e direcionamentos institucionais. Através delas, pudemos visualizar a intencionalidade de padronizar e modelar comportamentos.

Os direcionamentos prescritivos dos documentos nos permitiram verificar como foram efetivadas as políticas destinadas aos sujeitos do meio rural. Quando discorremos sobre as práticas agrícolas, apontamos como alguns organismos internacionais impulsionaram a implantação dos programas de extensão e assistência técnica rural no Brasil, assim como apresentamos como pano de fundo, qual foi o olhar institucional lançado sobre o trabalhador rural brasileiro. Ele era representado como um indivíduo carente, que demandava proteção e assistência, desprovido de valores, de sistematização no trabalho, incapacitado para as tarefas consideradas socialmente significativas. Esse olhar sempre entendeu que os trabalhadores rurais deveriam ser submetidos à vontade dos grupos esclarecidos, modernos e dominantes. Nesse sentido, reconstruir a trajetória da vivência dos trabalhos manuais e das práticas agrícolas desse grupo escolar, possibilitou que visualizássemos como o processo de modelagem do comportamento do indivíduo do meio rural se dava na prática, no cotidiano escolar. Entendemos inclusive, que tais práticas, foram o aspecto diferencial da cultura escolar dessa instituição.
Os documentos nos permitiram perceber que esse grupo escolar contribuiu significativamente para apresentar aos sujeitos do meio rural os aspectos e necessidades da vida moderna. Campanhas de higienização, técnicas de aperfeiçoamento das práticas manuais e agrícolas, posturas, condicionamento ao tempo, foram indicadores do que se queria modelar na população rural. Em seu percurso histórico a escola desempenhou a função de formadora dos filhos dos trabalhadores da Usina Tamoio. No entanto, essa formação ainda que tenha possibilitado o acesso de várias gerações de trabalhadores rurais à cultura escrita e aos códigos da modernidade, não contribuiu para a emancipação do homem do campo, não forneceu mecanismos ideológicos para que ele se mantivesse nas terras. As práticas agrícolas desenvolvidas ao longo de décadas no grupo escolar rural, serviram melhor para adaptar o trabalhador rural ao sistema capitalista moderno de produção do que para direcioná-lo à um sistema de agricultura familiar de subsistência.

Em sua caracterização, percebemos como essa instituição perpassou os tempos áureos do desenvolvimento econômico e social da comunidade local, ocasião em que recebeu uma grande quantidade de alunos de diversas seções de dentro da usina, e aproximadamente duas décadas depois, sentiu o esvaziamento, quando passou a vivenciar a decadência econômica e social daquele meio rural. A instituição chegou ao final dos anos de 1960 e início dos anos 1970, com um número bastante reduzido de alunos, reflexo do declínio por que passava a comunidade rural em que estava inserida. A venda das terras da família Morganti para o grupo empresarial Silva Gordo em 1969, praticamente sela o destino da instituição de ensino. Esse grupo implementou profundas transformações administrativas na empresa, visando torná-la competitiva no mercado industrial e financeiro, o que significou a diminuição da quantidade de mão de obra, ou seja, o processo de demissão em massa e a evasão dos trabalhadores rurais da Usina Tamoio, foram os fatores que causaram o esvaziamento que mais tarde culminou com o fechamento temporário dessa instituição de ensino.

Nesse sentido, vimos como ela acompanhou o apogeu e o declínio da família Morganti e sobreviveu ao período em que a comunidade rural onde se situava estava sendo submetida a um processo de modernização. Resistiu por um período de tempo e funcionou com um número bem reduzido de alunos, até que seu funcionamento passou a não ter mais significado social. Na década de 1980 com menos de duas dezenas de alunos, funcionou como 
um apêndice de uma escola urbana. Os registros não possuem informações sobre o cotidiano escolar nesse período. O que sabemos é que seus alunos, nessa época, eram os filhos dos empregados remanescentes da antiga estrutura agroindustrial, e que seus pais ainda lutavam na justiça para a resolução das situações trabalhistas pendentes. Durante os três anos finais da década de 1980, os filhos dos antigos trabalhadores que permaneceram morando na Fazenda Bela Vista, foram transportados para a cidade de Araraquara pelo poder público para realizarem lá seus estudos; seus pais depois foram então incorporados ao Projeto de Reforma Agrária a partir de 1989. O fechamento da escola encerrou um ciclo de vida da instituição coincidente com um ciclo do desenvolvimento da Usina Tamoio.

Os conhecimentos referentes às práticas agrícolas modernas que se queria incutir nos alunos, no entanto, não impediram a eliminação do trabalhador agrícola pelos métodos eficientes do novo modelo econômico imposto ao campo, tampouco, vieram como prescrições que instrumentalizassem o individuo do meio rural para sobreviver às demandas impostas pela industrialização no meio agrícola. Os conhecimentos transmitidos aos alunos do grupo escolar rural eram somente para capacitá-los para exercerem funções manuais, ligadas a terra, não para introjetar nos alunos a capacidade de organização e luta frente às reais necessidades por terra para produzir seus próprios alimentos. Desse modo, sem se vincular aos movimentos sociais de luta pela terra, o grupo escolar rural se prestou a reproduzir o ideário de dominação econômico e cultural das elites que na relação entre o rural e o urbano, primavam pelo urbano em detrimento do rural que era o lado considerado mais atrasado e desprovido socialmente.

No início de 1990, a comunidade do Assentamento Bela Vista apresentou à Delegacia Regional de Ensino de Araraquara uma demanda real de crianças em idade escolar, obrigando-a a reativar o prédio do antigo Grupo Escolar Comendador Pedro Morganti para receber esses alunos. A partir de então teve inicio um processo coletivo de construção um novo modelo educacional, bastante influenciado pela contribuição do movimento social de luta pela terra. Interessante apontar que, a partir do momento que passou a atender ao público oriundo do movimento de reforma agrária, as aulas de práticas agrícolas foram retomadas, e passaram a compor novamente os aspectos da cultura escolar da instituição de ensino. Entretanto, essas aulas de práticas agrícolas foram acrescidas de novos significados que redimensionaram sua função.
Atualmente a Escola Municipal de Ensino Fundamental do Campo "Prof. Hermínio Pagôtto é um modelo de escola do meio rural. Ela busca aproveitar a história de vida do trabalhador agrícola como demonstrativo para as novas gerações quais os processos de exploração e de pilhagem que foram submetidos os povos rurais. Mostra como foram desapropriados e expulsos do campo em algum momento de suas vidas pelo grande capital nacional e internacional, que sempre esteve aliado aos proprietários de grandes extensões de terra. A escola dos tempos atuais também busca com suas aulas de práticas agrícolas, fazer com que seus alunos estabeleçam vínculos com a terra, fazer com que se apropriem dos benefícios tecnológicos, culturais e científicos que a humanidade dispõe, e que os usem em práticas ecologicamente corretas, que possam ajudar na sustentabilidade do Planeta Terra. A Proposta Pedagógica da escola no momento estimula práticas agrícolas voltadas ao desenvolvimento da agricultura familiar e da agroindústria que agreguem valor à produção agrícola e pecuária do trabalhador rural e também busca respeitar os conhecimentos, as tradições e costumes e saberes do homem do campo. Isso tudo para que esses trabalhadores e suas futuras gerações, possam cada vez mais adquirir condições dignas e saudáveis de trabalho e permanência no meio rural.

\section{Referências}

ÁLBUM DE ARARAQUARA de 1948.

CAIRES, Ângela Cristina Ribeiro. Nem tudo era doce no império do açúcar: vida trabalho e lutas na usina Tamoios (1917-1969). Araraquara, 1993. 402p. Dissertação (mestrado) - Faculdade de Ciências e Letras, Universidade Estadual Paulista.

CALAZANS, Maria Julieta Costa. Para compreender a educação do estado no meio rural: traços de uma trajetória. In. THERRIEN, J. e DAMASCENO, M. N. Educação e escola no campo. Campinas: Papirus, p15-40, 1993.

COLEÇÃO DE LEIS E DECRETOS DO ESTADO DE SÃO PAULO. Decreto No 17.698 , de 26/11/47. v. 20, n.2, $2017 \quad$ RETRATOS DE ASSENTAMENTOS 
COLEÇÃO DE LEIS E DECRETOS DO ESTADO DE SÃO PAULO.

Decreto $\mathrm{N}^{\circ} 8.927$ de 19 de janeiro de 1938.

COLEÇÃO DE LEIS E DECRETOS DO ESTADO DE SÃO PAULO. Lei n. 2.648 de 17 de janeiro de 1936 .

FARIA FILHO, Luciano Mendes. Fazer História em educação com E. P. Thompson: Trajetórias de um aprendizado. In: FARIA FILHO, L. M. (org). Pensadores Sociais e História da educação. Belo Horizonte: Autentica, 2005.

FLORES, Ana Flávia. Grupos Escolares em áreas rurais: um estudo de caso na antiga Usina Tamoio em Araraquara/SP. Dissertação de Mestrado, UFSCAR - São Carlos, 2015.

LEITE, Sergio Celani. Escola Rural: urbanização e políticas educacionais. São Paulo: Cortez, 1999.

LIVRO DE ATAS DE REUNIÕES PEDAGÓGICAS do Grupo Escolar Pedro Morganti de 1950 a 1957.

LIVRO DE ATAS DE REUNIÕES PEDAGÓGICAS do Grupo Escolar Pedro Morganti de 1957 a 1962.

LIVRO DE ATAS DE REUNIÕES PEDAGÓGICAS do Grupo Escolar Pedro Morganti de 1962 a 1966.

LIVRO DE ATAS DE REUNIÕES PEDAGÓGICAS do Grupo Escolar Pedro Morganti de 1966 a 1975.

LIVRO DE MATRÍCULA “Feminino" do Grupo Escolar Rural Comendador Pedro Morganti de 1965 a 1967.

LIVRO DE MATRÍCULA “Masculino" do Grupo Escolar Rural Comendador Pedro Morganti de 1965 a 1967.

LIVRO DE MATRÍCULA “Secção Feminina” de 1942 a 1948 do Grupo
Escolar da Fazenda Bela Vista.

LIVRO DE MATRÍCULA “Secção Masculina” de 1942 a 1948 do Grupo Escolar da Fazenda Bela Vista.

LIVRO DE MATRÍCULA da $1^{\text {a }}$ Escola Mista da Secção Bela Vista em Tamoio - Araraquara - de 1975 a 1988.

LIVRO DE MATRÍCULA da $2^{\mathrm{a}}$ Escola Mista da Secção Bela Vista em Tamoio - Araraquara - de 1975 a 1984.

LIVRO DE MATRÍCULA das alunas do Grupo Escolar Rural Comendador Pedro Morganti de 1961 a 1964.

LIVRO DE MATRÍCULA do G.E.R. "Comendador Pedro Morganti” de 1968 a 1973-Feminino.

LIVRO DE MATRÍCULA do G.E.R.“Comendador Pedro Morganti” de 1968 a 1974-Masculino.

LIVRO DE MATRÍCULA dos alunos do Grupo Escolar Rural Comendador Pedro Morganti de 1961 a 1964.

PACHECO, Carlos Américo. Café e Cidades em São Paulo: Um estudo de caso de urbanização na região de Araraquara e São Carlos - 1880/1930. São Paulo, Unicamp, Dissertação de mestrado, 1988, mimeo.

REGISTRO ESCOLAR: Matrícula, Professores e Aparelhamento escolarModelo I - do Grupo Escolar Rural Comendador Pedro Morganti de 1949 a 1957.

SOUZA, Rosa Fátima. Alicerces da Pátria. Escola primária e cultura escolar no estado de São Paulo (1890-1976). Campinas: Mercado de Letras, 2009.

SOUZA, Rosa Fátima. Templos de Civilização: um estudo sobre a implantação dos grupos escolares no estado de São Paulo (1890-1910)., 
São Paulo, Edunesp,1998.

SOUZA, Rosa Fátima. Um Itinerário de Pesquisa sobre a Cultura Escolar. in: CUNHA, M.V. (Org.), Campinas: Autores Associados - (Coleção Polêmicas do Nosso Tempo:73), 2000.

TEIXEIRA, Reginaldo Anselmo. Grupo Escolar Comendador Pedro Morganti: estudo histórico sobre a cultura escolar de uma escola rural - 1942/1988. Dissertação de Mestrado FCL/UNESP - Araraquara, 2010.

THOMPSON, Edward Palmer. A Miséria da Teoria. Rio de Janeiro: Zahar, 1981.

Paz e Terra, 1987. V.I

.A Formação da Classe Operária Inglesa. Rio de Janeiro:

VIÑAO, Antônio. Historia de la educacion e historia cultural. Revista Brasileira de Educação, n.0, 1995). 